\title{
EFEK ANTIMIKROBA EKSTRAK RIMPANG KUNYIT (CURCUMA DOMESTICA) TERHADAP ESCHERICHIA COLI SECARA IN VITRO
}

\author{
Resa Putra Adiputra ${ }^{1}$ Irma Suswati ${ }^{2}$, Fathiyah $\mathrm{S}^{3}$
}

Fakultas Kedokteran Universitas Muhammadiyah Malang, Jl. Bendungan Sutami 188 A Sumbersari malang, Lowokwaru, Kota Malang, 65145, Indonesia, (0341) 582060

\begin{abstract}
ABSTRAK
Pengaruh Pemberian Boraks Peroral Sub Akut Terhadap Terjadinya Atrofi Testis Tikus Putih Jantan (Rattus novergicus strain wistar). Latar Belakang: Penggunaan boraks banyak disalahgunakan pada makanan. Boraks merupakan salah satu bahan toksik bagi organ testis sehingga dapat menyebabkan atrofi testis melalui penghambatan spermatogenesis. Tujuan: Membuktikan pengaruh pemberian boraks peroral sub akut terhadap terjadinya atrofi testis tikus putih jantan (Rattus novergicus strain wistar) dengan mengukur diameter testis, berat testis, dan jumlah tubulus seminiferus perlapangpandang. Metode: Eksperimental, The Post Test Only Control Group Design. Sampel yang digunakan 24 ekor dibagi 4 kelompok. Kelompok 1 (kontrol negatif), kelompok 2,3,dan 4 masing-masing dengan dosis $400 \mathrm{mg} / \mathrm{kgBB}, 500$ $\mathrm{mg} / \mathrm{kgBB}$, dan $600 \mathrm{mg} / \mathrm{kgBB}$ selama 28 hari. Dianalisis dengan oneway ANOVA, uji korelasi, dan uji regresi. Hasil penelitian dan diskusi: Terdapat perbedaan diameter testis dan jumlah tubulus seminiferus masing-masing dengan sig $\mathrm{p}=0,020(\mathrm{p}<0,05)$ dan sig $\mathrm{p}=0,00(\mathrm{p}<0,05)$, sedangkan pada berat testis tidak terdapat perbedaan dengan sig $\mathrm{p}=0,744$ $(\mathrm{p}>0,05)$. Analisis korelasi diameter testis $(\mathrm{p}=0,001),(\mathrm{r}=-0,613)$, jumlah tubulus $(\mathrm{p}=0,000),(\mathrm{r}=0,828)$, kenaikan boraks menyebabkan penurunan diameter testis dan peningkatan jumlah tubulus. Analisis regresi R2 diameter testis $=0,376$ dan R2 jumlah tubulus=0,685. Pada penelitian ini pengaruh boraks terlihat pada gambaran mikroskopis dibandingkan makroskopis, hal ini disebabkan oleh waktu paparan boraks yang kurang lama. Kesimpulan: Pemberian boraks peroral sub akut berpengaruh terhadap atrofi testis.Kata Kunci: Ekstrak rimpang temulawak, Staphylococcus aureus, KHM (Kadar Hambat Minimum), KBM (Kadar Bunuh Minimum).
\end{abstract}

\section{ABSTRACT}

The effects of sub-acute peroral borax to the occurrence of testicular atrophy of male white rats (Rattus novergicus wistar strain). Background: The use of borax is much abused on food. Borax was one of toxic for testicular organs so that it can cause testicular atrophy through inbibition of spermatogenesis Objective: Prove the effects of sub-acute peroral borax to the occurrence of testicular atrophy of male white rats (Rattus novergicus wistar strain) by measuring the diameter of testicular, the weight of testicular, and the number of seminiferous tubules each field of view. Methods: Experimental, The Post Test Only Control Group Design. The samples used are 24 rats which are divided into 4 groups. The first group (negative control), the second,third, and fourth group are respectively given a dose of $400 \mathrm{mg} / \mathrm{kg}, 500 \mathrm{mg} / \mathrm{kg}$, and $600 \mathrm{mg} / \mathrm{kg}$ for 28 days. Those are analyzed by oneway ANOVA, correlation test and regression test. Results and discussion: There is differences in the diameter of testicular and each amount of the seminiferous tubules with sig $p=0.020(p<0.05)$ and sig $p=0.00(p<0.05)$, whereas there is no difference in the weight of testicular with sig $p=0.744(p>0.05)$. Correlation analysis of the testicular diameter $(p=0.001),(r=0.613)$, the number of tubules $(p=0.000),(r=0.828)$, the increase in borax causes a decrease of testicular diameter and an increase in the number of tubules. Regression analysis R2 the diameter of testicular $=0.376$ and R2 the number of tubules $=0,685$. In this study, the effects of borax are seen on microscopic view rather than macroscopic one, This is caused by a lack time of exposure to borax. Conclusion: Giving of sub acute peroral borax affects on testicular atrophy.

Key words: Borax, Testicular Atrophy, diameter of testicular, weight of testicular, and number of seminiferous tubules.

\section{PENDAHULUAN}

Penyakit infeksi masih merupakan penyebab utama kematian dan bertanggung jawab atas penurunan status kesehatan jutaan manusia di seluruh dunia. Demikian juga di Indonesia, penyakit infeksi yang sebagian disebabkan oleh bakteri merupakan masalah besar di bidang kesehatan yang memerlukan penanganan yang serius karena berpotensi menginfeksi berbagai organ dalam tubuh dan menyebabkan komplikasi cukup serius (WHO, 2002).
Escherichia coli merupakan penyebab dari banyak infeksi. Salah satu diantaranya adalah infeksi enterik. Diare merupakan salah satu contoh kasus infeksi enterik akibat Escherichia coli yang sangat sering terjadi (Madappa, 2010). Hasil SKRT (Survei Kesehatan Rumah Tangga) pada tahun 2004 menyebutkan bahwa angka kematian akibat diare diperkirakan sekitar 23 per 100 ribu penduduk dan pada balita 75 per 100 ribu balita. Bahkan selama tahun 2006 sebanyak 41 kabupaten di 16 provinsi melaporkan KLB 
(Kejadian Luar Biasa) diare di wilayahnya. Dari hasil analisis Departemen Kesehatan pada tahun 1995-2001 menyatakan bahwa penyebab kasus diare di Indonesia didominasi oleh

Vibrio cholerae, Shigella sp., Salmonella typhi, dan Escherichia coli (Depkes, 2006). Selain diare, Escherichia coli juga dapat menyebabkan pneumoni, meningitis, infeksi intra-abdominal, infeksi traktus urinarius, dan infeksi lainya (Madappa, 2010).

Saat ini Escherichia coli dilaporkan telah resisten terhadap obat-obatan konvensional. Hal tersebut dapat terjadi terutama pada orang yang memiliki riwayat penggunaan antibiotik jangka panjang (WHO, 2002). Beberapa contoh golongan antibiotik yang dikabarkan telah resisten terhadap Escherichia coli adalah antibiotik golongan aminoglycosides dan third generation cephalosporins (Nicolle, 2001). Insiden bakteri resisten yang meningkat merupakan tanda bahaya dan diperkirakan berlanjut meningkat seiring dengan banyaknya pemakaian antibiotik yang tidak rasional (WHO, 2002).

Untuk itu perlu dipikirkan pengobatan alternatif ataupun pengobatan pendamping yang efektif dan efisien serta aman akan tetapi tetap berorientasi pada standar pelayanan kesehatan yang telah ada. Pengobatan pendamping yang dimaksud antara lain dengan menggunakan bahanbahan alami seperti tanaman obat.

Penggunaan tanaman sebagai obat-obatan saat ini sudah cukup populer. Hasil survey di Amerika terhadap 1.204 orang, menunjukkan 34\% menggunakan tanaman sebagai obat alternatif (Devitt, 2002). Survey lain yang dilakukan di Harvard tahun 1990-1997, penggunaan tanaman sebagai obat alternatif meningkat dari $2.5 \%$ menjadi 12.1\% (Browne, 2002). Alasan dari pemakaian tanaman sebagai obat karena mereka merasa terapi dengan cara tersebut cukup aman, dan efektif (Devitt, 2002).

Curcuma domestica atau kunyit, merupakan salah satu tanaman yang dikenal mempunyai khasiat obat. Tanaman ini merupakan tanaman tropis yang banyak terdapat di Asia Selatan dan Asia Tenggara. Kunyit banyak dikonsumsi di berbagai negara untuk berbagai tujuan, antara lain untuk bumbu masakan, bahanpewarna, dan obat tradisional. Penelitian tentang kunyit akhir-akhir ini cukup meningkat karena diduga kunyit memiliki berbagai efek yang menguntungkan seperti, anti inflamasi, anti kanker, dan anti infeksi. Efek antibiotik kunyit disebabkan bahan aktif yang terkandung di dalamnya yaitu diferuloylmethane atau curcumin (Rukmana, 2003). Selain curcumin, dilaporkan bahwa minyak atsiri (volatile oil) yang diisolasi dari rimpang kunyit (Curcuma domestica) mempunyai efek antimikroba (Maryland, 2004).

Dari hasil penelitian terdahulu diketahui ekstrak rimpang kunyit menghasilkan daya antimikroba terhadap MRSA (Methilcillin Resistant Staphylococcus aureus) dan Salmonella typhi (Kim et al, 2001). Hal ini menimbulkan pertanyaan apakah ekstrak rimpang kunyit dapat digunakan sebagai antimikroba terhadap Escherichia coli. Selain itu, belum ada bukti ilmiah mengenai penggunaan rimpang kunyit sebagai ramuan obat khususnya dalam pengobatan penyakit diare dan penyakit lain yang disebabkan oleh Escherichia coli. Untuk itu perlu dilakukan suatu penelitian untuk mendapatkan dasar teoritis dan bukti-bukti ilmiah tentang penggunaan rimpang kunyit dalam pengobatan penyakit diare serta penyakit lain yang disebabkan oleh Escherichia coli.

\section{BAHAN DAN METODE}

Alat yang dibutuhkan dalam pembuatan ekstrak rimpang kunyit adalah ekstraktor Soxhlet, rotary evaporator vacuum, labu destilasi, labu ekstraksi evaporasi, corong pisah, klem dan statis, timbangan analitik, water pump, water bath, kertas saring, saringan, pendingin spiral, dan vakum dengan selang plastik. Alat yang digunakan untuk uji ekstrak rimpang kunyit adalah ose, tabung steril, inkubator, mikroskop, mikropipet dan mikrotip steril, spektrofotometer, bunsen, korek api, spidol permanen, dan colony counter.

Bahan yang dibutuhkan untuk pembuatan ekstrak rimpang kunyit adalah rimpang kunyit, aquades steril, dan alkohol 96\% (sebagai pelarut). Bahan yang dibutuhkan untuk pembuatan sediaan bakteri adalah kristal violet, lugol, alkohol 96\%, safranin, dan minyak imersi. Bahan yang dibutuhkan dalam uji ekstrak rimpang kunyit adalah isolat bakteri Escherichia coli, ekstrak rimpang kunyit, medium EMB, nutrient Broth, dan aquades steril.

Uji TSI dengan cara Ambil satu koloni yang terpisah dari EMB dengan ose lurus ditanam pada TSI Agar, dengan cara menusuk sampai dasar tabung dengan ose lurus, kemudian menggoreskan ose tersebut secara zig-zag pada permukaan media. Diinkubasikan selama 18-24 jam pada suhu37 $\mathrm{C}$ dan dibaca hasilnya. Escherichia coli menunjukkan hasil reaksi: Alkali/Asam, H2S (-), dan Gas (+).

Penanaman bacteri Pada Media EMB. Bakteri yang akan diuji digoreskan pada agar EMB kemudian diinkubasi semalam. Koloni Escherichia coli pada EMB membentuk gambaran metallic sheen

Pembuatan Suspensi Bakteri Uji, Bakteri Escherichia coli diinokulasi pada nutrient broth kemudian diinkubasi dengan suhu $37^{\circ} \mathrm{C}$ selama $18-24$ jam. Selanjutnya nutrient broth tersebut distandardisasi menggunakan spektrofotometer untuk dibaca absorbansinya hingga didapatkan absorbansi yang setara dengan kepadatan bakteri $108 \mathrm{CFU} / \mathrm{ml}$. Nutrient broth kemudian diencerkan agar mendapatkan kepadatan yang diinginkan yaitu $106 \mathrm{CFU} /$ $\mathrm{ml}$. Untuk bakteri uji digunakan suspensi Escherichia coli sebesar $106 \mathrm{CFU} / \mathrm{ml}$.

Analisis data dilakukan dengan menggunakan fasilitas SPSS (Statistical Product and Service Solution) 17 For Windows. Penelitian ini menggunakan uji statistik One-way ANOVA (Analysis of Variance), pada taraf kepercayaan 95\% (á=0,05). Uji statistik ini digunakan untuk mengetahui apakah ada perbedaan yang signifikan antar perlakuan. Selain menggunakan uji statistik One-way ANOVA, pada penelitian ini juga menggunakan uji korelasi dengan taraf kepercayaan $95 \% \quad(\alpha=0,05)$. Uji ini bertujuan untuk mengetahui hubungan antara peningkatan konsentrasi ekstrak dengan penurunan jumlah koloni bakteri. Sedangkan untuk mencari kekuatan hubungan yang ada antara peningkatan konsentrasi ekstrak dengan penurunan jumlah koloni bakteri digunakan uji regresi linier. 


\section{HASIL DAN PEMBAHASAN}

\section{Uji Daya Antimikroba}

Pada penelitian ini tidak diteliti KHM dari ekstrak rimpang kunyit. Hal tersebut didasari oleh hasil eksplorasi yang telah dilakukan sebelumnya. Menurut hasil eksplorasi, suspensi ekstrak rimpang kunyit dan bakteri Escherichia coli membentuk warna keruh sehingga tidak dapat ditentukan nilai KHM. Hal ini disebabkan warna asli dari ekstrak rimpang kunyit adalah kuning, disamping itu kekeruhan yang terjadi karena terdapat reaksi antara ekstrak dengan nutrient broth yang digunakan, sehingga sulit bagi kita untuk menafsirkan derajat kekeruhan dalam tabung.

Hasil dari penghitungan jumlah koloni pada media EMB dengan menggunakan colony counter didapatkan jumlah koloni yang berbanding terbalik dengan peningkatan konsentrasi ekstrak rimpang kunyit.

Tabel 1. Hasil Perhitungan Jumlah Koloni Escherichia coli

\begin{tabular}{|c|c|c|c|c|c|c|c|}
\hline \multirow[t]{2}{*}{ tlangan } & \multirow{2}{*}{$\begin{array}{c}\mathrm{KB} \\
\text { (Kontrol } \\
\text { Bahan) }\end{array}$} & \multicolumn{5}{|c|}{ Konsentrasi Ekstrak } & \multirow{2}{*}{$\begin{array}{c}\text { KK } \\
\text { (Kontrol } \\
\text { Kuman) }\end{array}$} \\
\hline & & $3,125 \%$ & $6,25 \%$ & $12,5 \%$ & $25 \%$ & $50 \%$ & \\
\hline I & 0 & 260 & 103 & 35 & 12 & 0 & 453 \\
\hline II & 0 & 189 & 93 & 29 & 28 & 0 & 312 \\
\hline III & 0 & 201 & 152 & 41 & 14 & 0 & 460 \\
\hline IV & 0 & 247 & 112 & 46 & 25 & 0 & 387 \\
\hline Rerata & 0 & 224,25 & 115 & 38 & 19,75 & 0 & 403,5 \\
\hline
\end{tabular}

(Data primer, 2011)

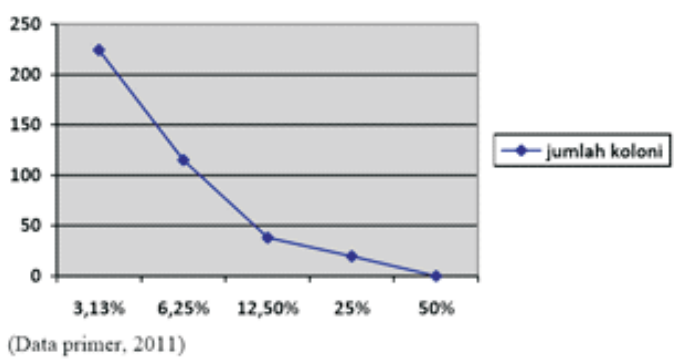

Gambar 1. Grafik Pertumbuhan Escherichia coli terhadap Perlakuanpertumbuhan koloni Escherichia coli pada medium EMB. Pada kontrol bakteri didapatkan pertumbuhan koloni, sedangkan pada kontrol bahan tidak didapatkan pertumbuhan koloni yang berarti bahan ekstrak rimpang kunyit yang digunakan tidak terkontaminasi. Pada konsentrasi ekstrak rimpang kunyit $3.125 \%, 6,25 \%, 12,5 \%$, dan $25 \%$ didapatkan pertumbuhan koloni dengan jumlah yang semakin menurun. Sedangkan pada konsentrasi 50\% tidak didapatkan pertumbuhan koloni Escherichia coli.

KBM ditentukan dengan cara menghitung jumlah koloni pada medium EMB yang berjumlah $<0,1 \%$ dari original inoculum. Dari hasil perhitungan yaitu $0,1 \% \mathrm{x}$ 403,5 = 0,404 koloni, jadi konsentrasi terendah yang mampu menumbuhkan kurang dari sama dengan 0,404 koloni bakteri ditetapkan sebagai KBM. Berdasarkan hasil penelitian didapatkan bahwa pertumbuhan koloni yang jumlahnya $<$ $0,1 \%$ dari original inoculum pada semua pengulangan terdapat pada konsentrasi 50\%. Maka dapat ditentukan KBM dari ekstrak rimpang kunyit pada penelitian ini adalah pada konsentrasi ekstrak 50\%.

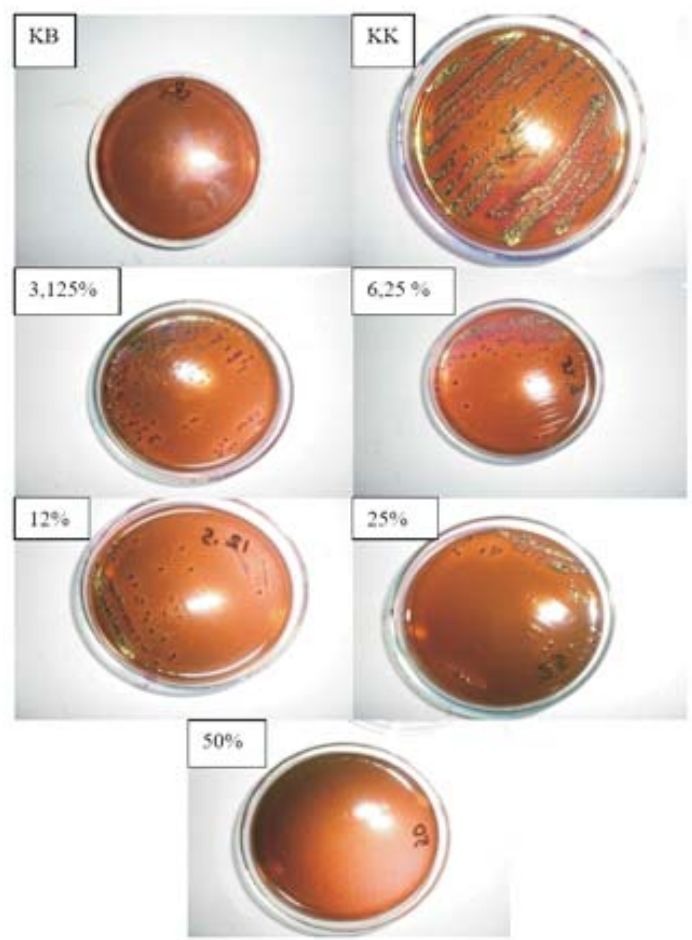

Gambar 2. Hasil Streaking Pada EMB

Pada hasil perhitungan jumlah koloni dengan menggunakan colony counter didapatkan data kuantitatif rasio sehingga dapat digunakan metode ANOVA satu arah untuk mengetahui signifikasi hasil perhitungan jumlah koloni terhadap konsentrasi. Dari uji statistik yang terlampir dalam lampiran 1, didapatkan nilai signifikasi $0,000(\mathrm{p}<0,05)$. Hal ini berarti bahwa antara pemberian konsentrasi ekstrak rimpang kunyit terdapat perbedaan bermakna pada jumlah koloni Escherichia coli. Untuk mengetahui kelompok mana saja yang mempunyai perbedaan jumlah koloni yang berbeda secara signifikan maka analisis dilanjutkan dengan melakukan post hoc test. Post hoc test ini berfungsi untuk mengelompokkan masing masing konsentrasi menjadi kelompok-kelompok yang berbeda. Hasil post hoc (Lampiran 2) menunjukkan bahwa terdapat perbedaan yang signifikan pada jumlah koloni yang tumbuh antara kelompok konsentrasi $0 \%$ dengan semua kelompok konsentrasi yaitu terhadap konsentrasi 3,125\%,6,25\%, 12,5\%, 25\%, dan $50 \%$. Kelompok konsentrasi 3,125\% terdapat perbedaan yang signifikan dengan semua kelompok konsentrasi yaitu terhadap konsentrasi $0 \%, 6,25 \%, 12,5 \%, 25 \%$, dan $50 \%$. Kelompok konsentrasi $6,25 \%$ juga terdapat perbedaan yang signifikan dengan semua kelompok konsentrasi yaitu terhadap konsentrasi $0 \%, 3,125 \%, 12,5 \%, 25 \%$, dan $50 \%$. Sedangkan kelompok konsentrasi 12,5\%, 25\%, dan 50\% terdapat perbedaan yang signifikan terhadap kelompok konsentrasi $0 \%, 3.125 \%$ dan 6,25\% saja.

Uji korelasi dilakukan untuk mengetahui adanya hubungan antara peningkatan konsentrasi ekstrak rimpang kunyit dengan penurunan jumlah koloni Escherichia coli. Hasil uji korelasi pearson diperoleh angka signifikasi 0,001 $(\mathrm{p}<0,05)$ dan $\mathrm{r}=-0,678$ yang berarti terdapat hubungan (korelasi) yang kuat dan bermakna antara konsentrasi ekstrak rimpang kunyit dengan jumlah koloni Escherichia coli. Nilai $r$ dengan tanda (-) menunjukkan bahwa semakin tinggi 
pemberian konsentrasi ekstrak rimpang kunyit maka pertumbuhan koloni Escherichia coli makin menurun (tanda negatif menunjukkan hubungan yang terbalik).

Untuk menyatakan keeratan hubungan antara peningkatan konsentrasi ekstrak rimpang kunyit terhadap penunuran jumlah koloni Escherichia coli digunakan uji regresi (Lampiram 3). Dari uji regresi didapatkan koefisien determinasi $\mathrm{R}$ sebesar 0,678 . Bila nilai koefisien determinasi $\mathrm{R}$ semakin mendekati 1 maka keeratan hubungan antar variabel semakin baik.

Penelitian ini dilakukan untuk membuktikan bahwa ekstrak rimpang kunyit memiliki aktivitas antimikroba terhadap Escherichia coli secara in vitro dengan menggunakan metode uji dilusi tabung yang dilanjutkan dengan inokulasi pada media EMB. Bahan uji dalam penelitian ini yaitu ekstrak rimpang kunyit yang dibuat dari rimpang kunyit yang diperoleh dari daerah Malang. Konsentrasi yang digunakan dalam penelitian ini adalah $0 \%, 3,125 \%, 6,25 \%$, $12,5 \%, 25 \%$, dan 50\%. KHM dapat ditentukan dengan cara melihat dan membandingkan tingkat kekeruhan pada tabung uji, namun pada penelitian ini KHM tidak dapat ditentukan. Meskipun KHM tidak dapat ditentukan, namun KBM dapat ditentukan yaitu pada konsentrasi ekstrak rimpang kunyit $50 \%$.

Hasil uji statistik didapatkan nilai $\mathrm{p}=0,000, \mathrm{r}=-0,678$, $\mathrm{R}=0,678$, dan $\mathrm{R}$ Square $=0,460$. Nilai $\mathrm{p}=0,000$ menunjukkan bahwa terdapat perbedaan yang signifikan antara setiap perlakuan dalam penelitian ini. Nilai $r=-0,687$ menunjukkan adanya hubungan yang signifikan dan bermakna. Tanda negatif menunjukkan semakin meningkat konsentrasi ekstrak semakin menurun jumlah koloni Escherichia coli. Nilai $\mathrm{R}=0,678$ menunjukkan adanya hubungan yang kuat antar kedua variabel yang ada pada penelitian ini. Nilai $\mathrm{R}$ Square $=0,460$ menunjukkan persentase variabel tergantung yang dipengaruhi oleh variabel bebas, yaitu hanya sebesar 46\%. Hal tersebut disebabkan oleh ketidakstabilan ekstrak. Ekstrak dapat bertahan dalam kondisi yang stabil dalam jangka waktu 1 bulan (Kim et al, 2003). Dalam penelitian ini ekstrak yang digunakan berusia 5 bulan. Selain itu ada suatu kecenderungan untuk suatu bakteri bermutasi sehingga menyebabkan resistensi dari bakteri (Cowan, 2001).

Zat dalam rimpang kunyit yang berkhasiat untuk menghambat atau membunuh mikroba adalah curcumin dan turunannya (Kim et al, 2003). Curcumin adalah kandungan senyawa kimia terbanyak dari curcuminoid serta merupakan bahan aktif utama yang didapat dari rimpang kunyit. curcumin (C21H20O6) adalah suatu pigmen kuning kunyit (pigmen polifenol) yang mudah larut dalam ether, kloroform, dan alkohol serta sedikit larut dalam benzene. Titik leleh curcumin adalah 178 C. Senyawa fenol yang terdapat dalam curcumin merupakan senyawa monohidroksi atau polihidroksi fenolik yang terikat sebagai senyawa glikosida, protein atau dengan alkaloid. Senyawa ini pada proses ekstraksi akan ditemukan dalam fraksi air ataupun dalam fraksi pelarut polar lainnya, tetapi karena curcumin dalam rimpang kunyit adalah senyawa yang mudah larut dalam pelarut polar maka untuk mengekstraksinya menggunakan pelarut etanol $96 \%$. Meskipun menggunakan etanol tetapi efek antimikroba yang didapat dari hasil penelitian ini diyakini bukan berasal dari etanol, karena ekstrak etanol telah mengalami proses evaporasi dan oven pada suhu 60 50 C (Felter, 2002).

Obat antimikroba mempunyai susunan kimiawi dan mekanisme yang berbeda antara obat satu dengan obat yang lainnya. Mekanisme kerja obat antimikroba diantaranya dapat menghambat sintesa dinding sel bakteri, merusak membran sel, menghambat sintesa protein, menghambat sintesa asam nukleat. Semua mekanisme kerja obat tersebut diharapkan dapat mengganggu kelangsungan hidup bakteri dan membunuh bakteri.

Curcumin adalah senyawa polifenol yang mempunyai mekanisme antimikroba melalui penghambatan enzim mikroorganisme yaitu pada enzim thiolase (enzim sulfhidril). Terhambatnya enzim thiolase menyebabkan tidak terjadinya proses oksidasi gugus sulfhidril (gugus -SH). Padahal proses oksidasi gugus sulfhidril ini berperan dalam pembentukan ikatan disulfida pada struktur sekunder protein. Tidak terbentuknya ikatan disulfida mengakibatkan struktur sekunder protein akan rusak sehingga menyebabkan terjadinya denaturasi protein bakteri. Selain itu, polifenol merupakan senyawa lipofilik yang dapat merusak membran sel dari bakteri. Kerusakan membran sel bakteri akan menyebabkan nutrisi-nutrisi penting yang diperlukan kuman untuk pembentukan energi tidak dapat masuk, akibatnya kuman akan mati karena tidak adanya energi dalam tubuhnya (Cowan, 2001).

Selain curcumin, diilaporkan bahwa minyak atsiri (volatile oil) yang diisolasi dari rimpang kunyit (Curcuma domestica) mempunyai efek antimikroba (Maryland, 2004). Sebagai senyawa terpenoid, mekanisme antibakteri minyak atsiri (volatile oil) diperkirakan melalui proses destruksi membran sel bakteri oleh komponen lipofilik (Cowan, 2001). Pada penelitian ini kemungkinan minyak atsiri tidak berperan sebagai antimikroba terhadap Escherichia coli, oleh karena pada proses evaporasi (suhu $6050 \mathrm{C}$ ) minyak atsiri tersebut akan menguap. Ekstrak rimpang kunyit selain memiliki efek antimikroba terhadap Escherichia coli juga didapatkan potensi antimikroba terhadap Salmonella typhii. Hal tersebut didapatkan dari penelitian terdahulu mengenai efek antimikroba ekstrak rimpang kunyit terhadap Salmonella typhii yang telah dilakukan oleh Cholid pada tahun 2006.

Menurut penelitian tersebut didapatkan KHM yang tidak teridentifikasi dan KBM pada konsentrasi 50\%. Bila dibandingkan dengan penelitian ini hasil yang didapatkan relatif sama. Oleh karena itu dapat disimpulkan bahwa esktrak rimpang kunyit ini kemungkinan besar juga memiliki efek antimikroba terhadap spesies bakteri lain yang termasuk dalam famili Enterobacteriaceae. Hal tersebut didasari oleh terbuktinya efek antimikroba ekstrak rimpang kunyit terhadap dua spesies bakteri yang termasuk dalam satu famili tersebut (Escherichia coli dan Salmonella typhii). Namun masih diperlukan penelitian lebih lanjut apakah ekstrak ini dapat memberikan efek antimikroba juga pada spesies lain dalam famili Enterobacteriaceae selain Escherichia coli dan Salmonella typhii. 


\section{SIMPULAN}

Ekstrak rimpang kunyit memiliki aktivitas antimikroba terhadap Escherichia coli. KBM ekstrak rimpang kunyit terhadap Escherichia coli dalam penelitian ini adalah konsentrasi 50\%. Peningkatan konsentrasi ekstrak rimpang kunyit berhubungan dengan hambatan pertumbuhan bakteri Escherichia coli.

\section{DAFTAR PUSTAKA}

Azwar Azrul, 2004. Metodologi Penelitian Kedokteran dan Kesehatan Masyarakat. Jakarta: Binarupa Aksara.

Biodiversity, 2004. Features of Colory Mophology [online], diunduh 28 januari 2011, didapat dari: http:// www.science,wennesaw.edu/biophys/biodiversity/ eubacteriales/eubpix.html.

Braunwald, E; Fauci, A,S.; Kasper, D.L.; Hamer, S,L.; Lango, D,L.; Jamson J,L., 2001. Harrison's Principle of Internal Medicine 15th Edition. United States of America: The Mc. Graw hill companies inc.

Browne, M, 2002. Alternatives Medicine Use in The General Public [online], diunduh 21 november 2010, didapat dari: http://www.altmed.creugton.edu/ peslop/ general_population.html.

Cholid, R, 2006. Efek Antimikroba Ekstrak Rimpang Kunyit Terhadap Salmonella Typhi Secara In Vitro [online], diunduh 15 november 2010, didapat dari: http:// www.brawijya.ac.id/library/2006/sep/172590.html.

Cowan, M, 2001. Plant Product as Antimicrobial Agent Ohio. Departement of microbiology miamy universtyoxford.

Devitt, M, 2002. Complementary Care in The United Kingdom [online], diunduh 15 november 2010, didapat dari: http://www.accupunture_today.com/achieve / 2000/sep/ 09cameu.html.

Dzen, M, dkk., 2003. Bacteriology Medic. Malang: Bayu Medica Publishing.

Dahlan, S, 2009. Statistik untuk Kedokteran dan Kesehatan. Jakarta: Salemba Medika.

Felther, H; Llyod, U., 2002. Curcuma [online], diunduh 14 desember 2010, didapat dari: http://ibinilo.org/ herbmed/electric/kings/cucuma.html.

Finegold, S , 2001. Diagnostic Microbiology. Toranto: Mosby Company.

Harns, R, 2001. Tanaman minyak atsiri. Jakarta: PT. Penebar Swadaya.

Ismael, S; Sastroasmoro, S., 2005. Dasar-Dasar Metodology Penelitian Klinis. Jakarta: Binarupa Aksara

Jawetz, E; Melnwick, A; Adelberg, J., 2008. Microbiology. Jakarta: EGC.

Kim et al, 2003. Curcumin [online], diunduh 22 november 2010, didapat dari: http://www.ladr.contex.com/ curcumin.html. Linadarkis, N, 1998. Microbiology dan Immunology 2th Edition. Newyork: Mc braw nill companies inc. 